\title{
Communication
}

\section{Effects of Riboflavin Deficiency on the Synthesis of Ester Forms of Riboflavin in the Rat Lens}

\author{
Shigeru ONO, Hiroko HiRANO, Susumu HAMAJIMA, \\ and Saburo HORIUCHI ${ }^{1}$ \\ Department of Biochemistry, School of Medicine, \\ Iwate Medical University, Morioka 020, Japan
}

(Received July 24, 1981)

Key Words riboflavin, deficiency, rat lens, synthesis, FAD, FMN

A few reports were found on the riboflavin $\left(B_{2}\right)$ in the eye tissues in various species (1-3).

Flavin compound in the eye of Rana nigromaculata concentrates in the choroid, iris, ciliary body and is not present in other parts. The amount and distribution of flavin compound in the eye varies considerably in different species of frogs (4).

The presence of $\mathrm{B}_{2}$ in the lens of haddock (Gadus aeglefinus), rabbit and other species could not be demonstrated (5).

The synthesis of ester forms of $\mathrm{B}_{2}$ in the lenses of various species has not yet been determined, however, it should be noted that flavin-containing enzymes such as glutathione reductase exist in the lens $(6,7)$. Furthermore, we have reported that ester forms of $B_{2}$ are synthesized from free riboflavin in the rat lens in vitro as well as in other tissues, and that synthesis of ester forms of $B_{2}$ is carried out fairly actively $(8)$.

In the present study, the changes in formation of ester forms of $B_{2}$ in the lenses of $\mathrm{B}_{2}$-deficient rats were investigated.

Wistar strain male rats weighing about $50-70 \mathrm{~g}$ were maintained on a $\mathrm{B}_{2}$ deficient diet as reported previously (9). Experiments were carried out at 4 and 8 weeks, respectively, after being fed a $\mathrm{B}_{2}$-deficient diet (Oriental yeast Co., Japan). NADPH-cytochrome $c$ reductase activity $(10)$, glutathione reductase activity (11) and $\mathrm{B}_{2}$ content (12) in the liver, and glutathione reductase activity in the lens (7) were determined as a marker of $\mathrm{B}_{2}$-deficient status.

Lenses from excised eyes were carefully removed by the posterior approach and homogenized in $0.1 \mathrm{M}$ phosphate buffer ( $\mathrm{pH} 7.5$ ) containing ATP $1 \mathrm{mM}, \mathrm{MgCl}_{2} 1 \mathrm{~mm}$ and $\mathrm{ZnSO}_{4} 0.1 \mathrm{~mm}$ to give a final concentration of $60 \mathrm{mg}$ wet weight per $\mathrm{ml}$. Two $\mathrm{ml}$ of this homogenate was incubated with $0.02 \mathrm{ml}$ of $1.5 \mu \mathrm{Ci} / \mathrm{ml} \mathrm{D}-\left[2-{ }^{14} \mathrm{C}\right]$-riboflavin solution (specific activity $31.0 \mathrm{mCi} / \mathrm{mmol}$ ) for $60 \mathrm{~min}$ at $37^{\circ} \mathrm{C}$ after which it was

1 小野 繁, 平野浩子, 浜島 進, 堀内三郎 
cooled to $4^{\circ} \mathrm{C}$ and centrifuged at $10,000 \times g$ for $60 \mathrm{~min}$ to remove insoluble protein and particulate matter. Unless otherwise stated, all experimental procedures were carried out in a laboratory illuminated with dimmed or red light. Quantitative determination of radioactivity of flavin fractions was carried out using a Sephadex G-15 column $(1.5 \times 20 \mathrm{~cm})$. An aliquot of supernatant of incubation medium was eluted with $0.025 \mathrm{M}$ phosphate buffer $(\mathrm{pH} \mathrm{7.0)}$ ), fractions of $2 \mathrm{ml}$ were collected at room temperature. One $\mathrm{ml}$ aliquots of each tube were added to $10 \mathrm{ml}$ of dioxane containing $7 \mathrm{~g}$ of 2,5-diphenyloxazole, $300 \mathrm{mg}$ of 1,4-bis[2-(4-methyl-5-phenyl-

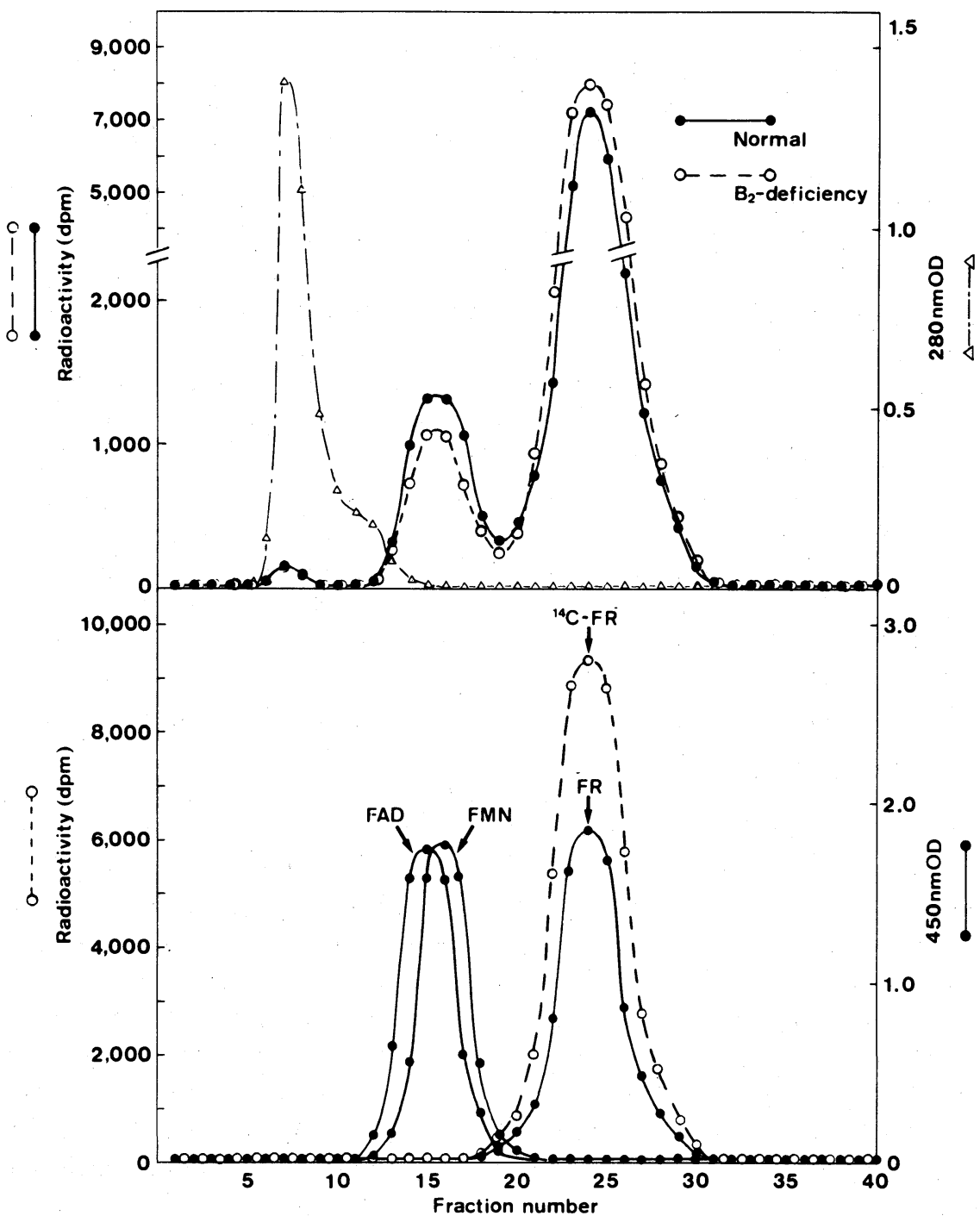

Fig. 1. 
oxazolyl)]benzene and $100 \mathrm{~g}$ naphthalene per liter and the radioactivities of the samples were counted in a liquid scintillation counter (Aloka Liquid Scintillation System, LSC-900). The radioactivity was eluted in three peaks when the supernatant of incubation medium was chromatographed using a Sephadex G15. The first, minor peak containing a lesser amount of radioactivity also contained lens proteins as measured by UV absorption at $280 \mathrm{~nm}$ showing the presence of riboflavin binding protein in the lens as reported previously $(8)$. The second, large peak of radioactivity represents the fraction of ester forms of $B_{2}$ synthesized from ${ }^{14} \mathrm{C}$-riboflavin and the third, larger peak was ${ }^{14} \mathrm{C}$-riboflavin used as a substrate (Fig. 1).

Identification of the two major peaks was carried out as follows. Fractions of the second and third peaks were pooled, respectively, and flavin compounds were concentrated according to the method of Crammer(13), then separation of flavin compounds was carried out using a DEAE Sephadex A-25 ion exchange column according to the method of Fazekas (14), and paper partition chromatography. When labelled riboflavin alone was filtered through a Sephadex G-15 column, all radioactivity emerged in the position of the third peak (Fig. 1). Furthermore, an authentic standard of flavin adenine dinucleotide (FAD), flavin mononucleotide (FMN) and riboflavin, respectively, was eluted on a Sephadex G-15 and each fraction of FAD, FMN and riboflavin was monitored by measurement of the absorbance at $450 \mathrm{~nm}$ (Fig. 1). The fraction of ester forms of $B_{2}$ formed by lens homogenate from ${ }^{14} \mathrm{C}$-riboflavin was a mixture of FAD and FMN and the amount of ester forms was expressed as $\mathrm{nmol} / \mathrm{g}$ wet weight of lens for $1 \mathrm{hr}$ at $37^{\circ} \mathrm{C} .{ }^{14} \mathrm{C}$ Riboflavin was purchased from Radiochemical Centre, England. NADPHcytochrome $c$ reductase, glutathione reductase and $B_{2}$ content in the respective tissues of $B_{2}$-deficient rats showed a significantly low level of $B_{2}$ status as shown in Table 1.

Decreases in synthesis of ester forms of $B_{2}$ were observed in the lenses of rats which had been fed a $B_{2}$-deficient diet for 8 weeks but not for 4 weeks as shown in

Fig. 1. Elution profiles of radioactive flavins in the incubation mixture of lens homogenate of normal and $\mathrm{B}_{2}$-deficient rats as compared with authentic standards of three forms of $B_{2}$ on a Sephadex G-15 column. Lens homogenate containing ATP and some chemicals was incubated with ${ }^{14} \mathrm{C}$-riboflavin for $1 \mathrm{hr}$ at $37^{\circ} \mathrm{C}$. An aliquot of supernatant of incubation medium was eluted with $0.025 \mathrm{M}$ phosphate buffer $(\mathrm{pH}$ 7.0), fractions of $2 \mathrm{ml}$ were collected at room temperature. One aliquots of each tube were added to $10 \mathrm{ml}$ of dioxane scintillator and the radioactivity of the samples were counted in a liquid scintillation counter. Protein concentration in each fraction was monitored by measurement of the absorbance at $280 \mathrm{~nm}$. Authentic standard of FAD, FMN and riboflavin, respectively, was eluted on a Sephadex G-15 and each fraction of FAD, FMN and riboflavin was monitored by measurement of the absorbance at $450 \mathrm{~nm}$, furthermore, ${ }^{14} \mathrm{C}$-riboflavin alone was filtered through a Sephadex G-15 column and its radioactivity was counted. Abbreviations: FAD, flavin adenine dinucleotide; FMN, flavin mononucleotide; FR, riboflavin. 


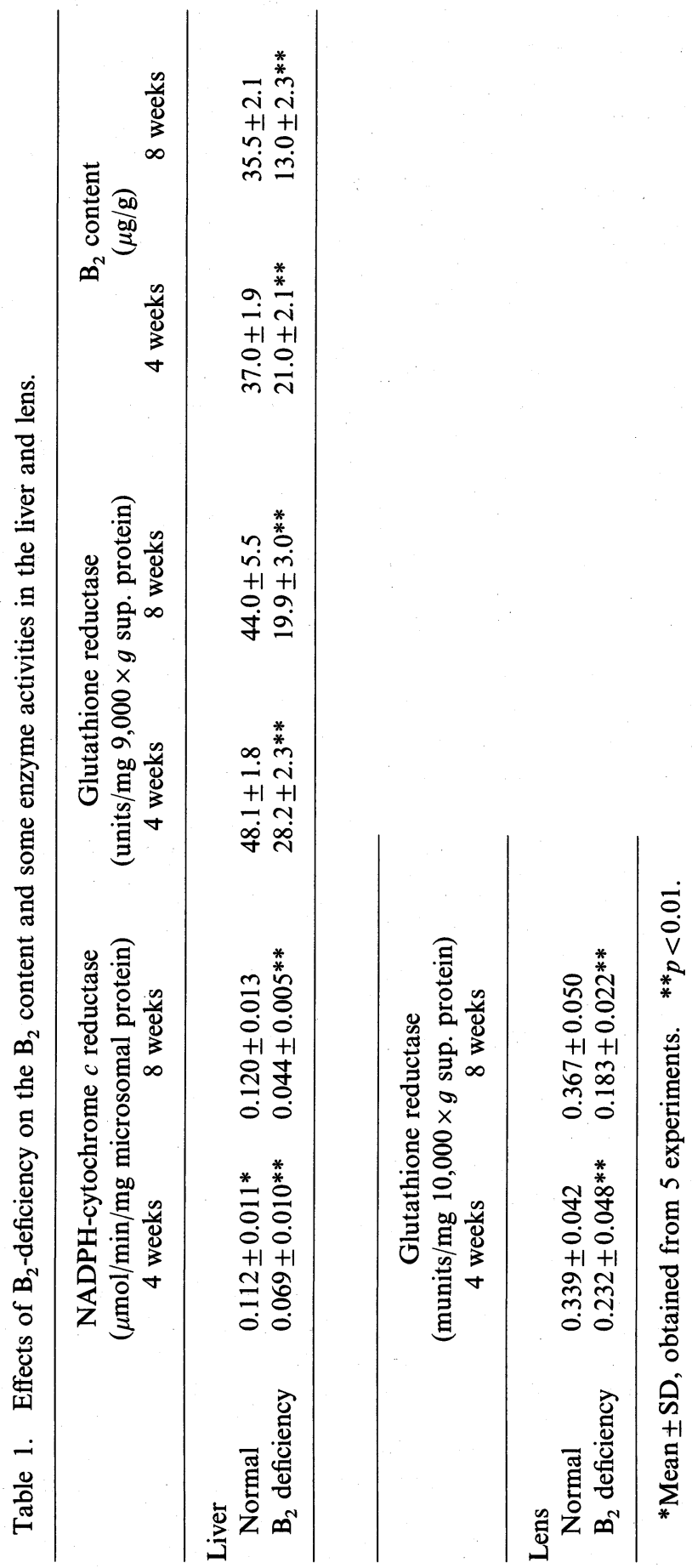


Table 2. Formation of ester forms of riboflavin from ${ }^{14} \mathrm{C}$-riboflavin by lens homogenate of $\mathrm{B}_{2}$-deficient rats.

Wistar strain male rats weighing about $50 \mathrm{~g}$ were maintained on a $\mathrm{B}_{2}$-deficient diet. Determination of formation of ester forms of riboflavin in the rat lens was carried out at 4 and 8 weeks, respectively, after being fed a $B_{2}$-deficient diet. See text for details. The amount of ester forms of $\mathrm{B}_{2}$ formed by lens homogenate from ${ }^{14} \mathrm{C}$-riboflavin was expressed as nmol/g wet weight of lens for $1 \mathrm{hr}$ at $37^{\circ} \mathrm{C}$.

\begin{tabular}{lcc}
\hline & \multicolumn{2}{c}{$\begin{array}{c}\text { Ester forms of riboflavin } \\
(\mathrm{nmol} / \mathrm{g} \text { lens wet weight } / \mathrm{hr})\end{array}$} \\
4 weeks & 8 weeks \\
\hline Normal & $1.474 \pm 0.152^{*}$ & $1.310 \pm 0.108$ \\
$\mathrm{~B}_{2}$ deficiency & $1.518 \pm 0.146$ & $1.089 \pm 0.027$ \\
\hline & N.S. & $p<0.05$ \\
\hline
\end{tabular}

*Mean $\pm \mathrm{SD}$, obtained from 4 experiments. N.S., not significant; $p, t$-test.

Table 2.

We have reported that the amount of high molecular phosphate compounds was dropped in the lens of $\mathrm{B}_{2}$-deficient rat (15), furthermore, we have demonstrated that the activity of glucose-6-phosphate dehydrogenase (G-6-PD) which is the enzyme of the main ATP-generating system in the lens was also reduced, then suggested that lowered G-6-PD activity may lead to a phosphorylation insufficiency in the lens of $B_{2}$-deficient rats (9).

These results are consistent with those found in this $B_{2}$-deficient experiment, i.e., phosphorylation of $\mathrm{B}_{2}$ in the lens was reduced in $\mathrm{B}_{2}$-deficient rats.

It is suggested that $B_{2}$ deficiency would bring about metabolic disorder in the lens which requires flavin ester as a coenzyme of the oxidoreduction system to maintain transparency.

\section{REFERENCES}

1) von Euler, H., and Adler, E. (1934): Über das Vorkommen von Flavinen in tierischen Geweben. Z. Physiol. Chem., 233, 105-112.

2) von Euler, H., and Adler, E. (1934): Über Flavin und einen blau-fluorescierenden Stoff in der Netzhaut der Fischaugen. Z. Physiol. Chem., 228, 1-12.

3) Adler, E., and von Euler, H. (1938): Lactoflavin in the eyes of fish. Nature, 141, 790-791.

4) Yagi, K. (1951-52): Flavin compound in frog's eye. Jpn. J. Physiol., 2, 27-33.

5) van Heyningen, R., and Linklater, J. (1976): Serine and threonine ethanolamine phosphate diesters, and some other unusual compounds in the lens of the cod fish (Gadus morhua) and haddock (Gadus aeglefinus). Exp. Eye Res., 23, 29-34.

6) Srivastava, S. K., Villacorte, D., Arya, D. V. (1973): Distribution of glutathione reductase in lens epithelium, cortex and nucleous in various species and in human 
cataractous lenses. Exp. Eye Res., 16, 519-521.

7) Rogers, K. M., and Augusteyn, R. C. (1978): Glutathione reductase in normal and cataractous human lenses. Exp. Eye Res., 27, 719-721.

8) Ono, S., Hirano, H., and Sato, Y. (1981): Formation of flavin adenine dinucleotide and flavin mononucleotide by lens homogenate. Exp. Eye Res. (in press).

9) Ono, S., Hirano, H., Kudo, K., and Obara, K. (1976): Some biochemical changes in lenses of riboflavin deficient rats. Intl. J. Vit. Nutr. Res., 46, 422-426.

10) Masters, B. S. S., Williams, C. H., Jr., and Kamin, H. (1967): Methods in Enzymology, Academic Press, New York, Vol. 10, pp. 565-573.

11) Racker, E. (1955): Methods in Enzymology, Academic Press, New York, Vol. 2, pp. 722-725.

12) Yagi, K. (1971): Methods in Enzymology, Academic Press, New York, Vol. 18B, pp. 290-296.

13) Crammer, J. L. (1948): Paper chromatography of flavine nucleotides. Nature, 161, 349-350.

14) Fazekas, A. G. (1975): Chromatographic and radioisotopic methods for the analysis of riboflavin coenzymes, in Riboflavin, ed. by Livlin, R. S., Plenum Press, New York, pp. $88-89$.

15) Ono, S., Hirano, H., Ono, M., Nagato, K., and Obara, K. (1977): Effect of riboflavin deficiency on the ${ }^{32} \mathrm{P}$ turnover in the macromolecular phosphate compounds of the rat lens. Intl. J. Vit. Nutr. Res., 47, 345-348. 